\title{
Effect of Seed Inoculation on Alfalfa Tolerance to Water Deficit Stress
}

\author{
Mahnaz ZAFARI ${ }^{1 *}$, Ali EBADI ${ }^{2}$, Sodabeh JAHANBAKHSH GODEHKAHRIZ² \\ ${ }^{1}$ University of Mohaghegh Ardabili, Faculty of Agriculture, Department of Agronomy and Plant Breeding, Iran; mahnaz.zafari@yahoo.com \\ ${ }^{2}$ University of Mohaghegh Ardabili, Faculty of Agriculture, Department of Agronomy and Plant Breeding, \\ Iran;ebadi@uma.ac.ir;jahanbakhsh@uma.ac.ir
}

\begin{abstract}
Water deficit is one of the most important environmental stresses that adversely affect crop growth and production and mycorrhizal fungi and symbiotic bacteria have important role in resistance to drought stress. The effect of biofertilizers on alfalfa stress tolerance was studied at the greenhouse condition. Treatments comprised three water-deficit stresses (35\%, 55\% and 75\% of field capacity) and four seeds inoculations (Glomus mosseae, Sinorhizobium meliloti, G. mosseae + S. meliloti and non-inoculated). Water-deficit stress decrease cell membrane stability (39\%), total Chl (24.05\%), carotenoid (35.55\%), quantum yield $(50.64 \%)$ and forage yield $(28.20 \%$ ), while increased the proline and soluble sugars content (68.55 and 46.53\% respectively) and osmotic potential $(45.84 \%)$. The inoculation of seeds increased the capability of the plants in counteracting the stress, so that the production of compatible solutes was increased and the photosynthetic indices, proline, osmotic potential, membrane stability and forage yield were improved by seed inoculation. Mycorrhiza improved photosynthetic indexes and proline, but bacteria had more efficacy on membrane stability and forage yield. However, double inoculation due to the synergistic effect of mycorrhiza and Sinorbizobium, had the greatest effect than Solitary inoculation. Our results suggest that biofertilized alfalfa plants were better adapted than non- biofertilized ones to cope with water deficit.
\end{abstract}

Keywords: drought, Medicago sativa, mycorrhizal fungi, resistance, symbiotic bacteria

\section{Introduction}

Water deficit changes the pathways of some metabolic processes. This stress ceases cell development and plant growth due to the low turgor potential (Sunka et al., 2003). In addition, decrease in water uptake by roots is accompanied by decrease in cell turgor resulting in lower cell division and cell growth inhibition (Yordanov and Tsonev, 2003). Low water potential in plant tissues results in stomatal closure, reduces photosynthesis, affects respiration, destroys proteins and enzymes, results in production of toxic substances, hormonal disruption and increased level of different kinds of reactive oxygen species (Shimshi et al., 1992) and injures the pigments and plastids (Follows and Boyer, 1996).

Plants may use of various strategies for dealing with stresses. Protecting cell membranes and osmotic adjustment during stress is known as an important method for improving stress tolerance. Osmotic adjustment can be controlled by converting polysaccharides (starch and fructan) and oligosaccharides (sucrose and glucose) to each other (Cui et al, 2004). One of the most important methods for mitigating the impact of stress is using biofertilizers. Biofertilizers are preservatives abounded with beneficial soil-borne organisms as their metabolite products which are colonized around roots or internal parts of the plant and stimulate the growth of the host plant in different ways (Singh and Kapoor, 1999). The benefits of growthinducing bacteria to plants include stimulation of the plants growth by rhizosphere bacteria through fixing atmospheric nitrogen, increasing the availability of nutrients in rhizosphere, increasing root contact area, producing growth regulators and improving beneficial symbiosis with host plant at different growth stages (Chogan, 2003). Through improving the ability of host plant in absorbing nutrients, such as $\mathrm{N}$ and $\mathrm{P}$ in particular, from unavailable resources and augmenting the activity of soil microbial community, mycorrhiza and rhizobia increase the plant hormones like auxin and enhance the waterdeficit resistance (Zahir et al., 2000; Barea et al., 2005). Given the fact that the application of chemical fertilizers is accompanied by the pollution of soil and environment, the application of biological sources for improving the tolerance and performance of the plants can be regarded as the useful economic, social and environmental aspects of these materials.

The contribution of Rhizobium and arbuscular mycorrhizal fungi (AM) to soil fertility, productivity and crop yield have been well documented (Bir et al., 2000). The success co-inoculation depends not only on the infectivity of microbes 
but also on the compatibility of the interactions between the participants (Puppi et al., 1994). Compatible combinations of nitrogen fixing Rhizobium bacteria and AM may result in enhanced effects on plant development in the various microsymbiont legume systems (Bir et al., 2000).

The application of bio-inoculants - Arbuscular Mycorrhizal Fungi (AMF) and Rhizobium - for improving of droughttolerant plants is one of great importance because it minimizes the production costs and environmental hazards (Javaid, 2010). Therefore, the objective of this study was determining the effect of Arbuscular mycorrhizal fungi (AMF) and Rbizobium (R) inoculation; individually or in combination $(A M F+R)$ on water deficit stress alleviation in alfalfa plants, in order to improve growth, photosynthetic indices, osmotic adjustment and forage yield.

\section{Materials and Methods}

\section{Experimental design}

This study was conducted as a factorial experiment based on completely randomized design (CRD) with three replications under controlled conditions in University of Mohaghegh Ardabili, in 2014. The water limitation imposed at $35 \%, 55 \%$ and $75 \%$ of field capacity (FC) and seeds inoculated by mycorrhiza (Glomus mosseae), rhizobium (Sinorbizobium meliloti), double inoculation $(S$. meliloti $+G$. mosseae) and non-inoculation (as control). Field capacity was determined by gravimetric method.

The seeds were prepared from Seed and Plant Improvement Institute of Karaj, Iran. Then, seeds were inoculated with mycorrhiza ( $G$. mosseae) and rhizobium $(S$. meliloti) for which the seeds were treated with $10 \mathrm{~g}$ inoculators per $100 \mathrm{~g}$ seed and Arabic Gum solution was used for improving the viscosity of inoculators to the seeds. For double inoculation, five grams of each stimulator mixed with each other per $100 \mathrm{~g}$ seeds. Sinorhizobium was prepared from Institute of Mehr Asia biotechnology, and mycorrhizal inoculum from Turan Institute of Biotechnology.

\section{Photosyntheticpigments}

Fresh leaf tissue was used for the measurement of Chlorophyll. $200 \mathrm{mg}$ of leaf tissue was gradually grinded using $80 \%$ acetone in order to extract Chlorophyll into the acetone solution. The final volume of the solution was then brought up to $20 \mathrm{ml}$ using $80 \%$ acetone. The resulted solution was centrifuged at $400 \mathrm{rpm}$ for $10 \mathrm{~min}$ and the optical absorption of the supernatant was then read at 470, 645 and $663 \mathrm{~nm}$ using a spectrophotometer. Chlorophyll and carotenoids contents were obtained according to Arnon (1967).

Chlorophyll $a=\left(19.3 \times \mathrm{A}_{663}-0.86 \times \mathrm{A}_{645}\right) \mathrm{V} / 100 \mathrm{~W}$

Chlorophyll $b=\left(19.3 \times \mathrm{A}_{645}-3.6 \times \mathrm{A}_{663}\right) \mathrm{V} / 100 \mathrm{~W}$

Carotenoid $=\left(1000 \mathrm{a}_{470}-1.82 \mathrm{C}_{\mathrm{a}}-85.02 \mathrm{C}_{\mathrm{b}}\right) / 198$

\section{Quantumyield}

The quantum yield was measured by the uppermost full expanded leaf using a fluorometer (Chlorophyll fluorometer; Optic Science-OS-30 USA). So, the plants were adapted to darkness for 20 minutes by using one special clamp. Then, the $\mathrm{PS}_{\text {II }}$ fluorescence was measured in $1000\left(\mu \mathrm{M}\right.$ photon $\left.\mathrm{m}^{-2} \mathrm{~s}^{-1}\right)$, and calculation was performed using following equations
(Arnon, 1949):

$$
\varnothing \mathrm{PSII}=(\mathrm{Fm}-\mathrm{Fo}) / \mathrm{Fm} \text {, }
$$

where:

ØPSII was quantum yield amount of photosystem II,

Fm was maximum fluorescence after a saturated light pulse on plants adapted to darkness and

Fo was the minimal fluorescence in the light adapted, which was determined by illumination with far-red light.

\section{Proline}

For the measurement of proline, $500 \mathrm{mg}$ of plant fresh tissue was crushed in $10 \mathrm{ml}$ sulpho acetic acid solution to obtain a homogeneous mixture. The homogenate filtrated using Whatman filter paper no. 2 and 2 ml dimenhydrinate reagent and $2 \mathrm{ml}$ glacial acetic acid were added. The extract was mixed and stirred on bain-marie at $100{ }^{\circ} \mathrm{C}$ for one hour and then $4 \mathrm{ml}$ toluene was added and the extract was vortexed to form two separate phases. The supernatant absorbance was read at $520 \mathrm{~nm}$ by a spectrophotometer (Bates et al., 1973).

\section{Soluble sugars assay}

To measure soluble sugars, $500 \mathrm{mg}$ of leaf tissue was first completely homogenized. Then $5 \mathrm{ml}$ of $95 \%$ ethanol were added and vortexed in test tube for 30 seconds. The supernatant was then centrifuged at 3,500 rpm for $15 \mathrm{~min}$ and used to measure the soluble sugars according to the method proposed by Ndoumou et al. (1996). The absorbance was measured using a spectrophotometer at $625 \mathrm{~nm}$.

\section{Osmoticpotential}

The osmotic potential was determined based on the electrical conductivity (Janardhan and Krishnamoorthy, 1975). One gram of fresh leaf tissue was crushed in $25 \mathrm{ml}$ distilled water. Electrical conductivity (EC) was measured at $25^{\circ} \mathrm{C}$. Osmotic potential was calculated using the following equations:

$$
\begin{aligned}
& \mathrm{DF}=\mathrm{M} \times 25 / \mathrm{W} \\
& \mathrm{OP}=\mathrm{EC}\left(\text { in } 25^{\circ} \mathrm{C}\right) \times 0.36 \times \mathrm{DF} / 0.987, \\
& \text { where: } \\
& \mathrm{DF} \text { is the dilution factor, } \\
& \mathrm{M} \text {, tissue fresh weight, } \\
& \text { W, gram water content in one gram fresh tissue and } \\
& \mathrm{OP} \text { is osmotic potential. }
\end{aligned}
$$

\section{Cell membrane}

The cell membrane stability was measured by Blum and Ebercon (1981) method. Ten expanded leaves used half for treating and the rest as control. The control samples were soaked in $30 \mathrm{ml}$ of distilled water and the treatments in $30 \mathrm{ml}$ of $30 \% \mathrm{PEG}_{6000}$ solution. The samples were situated for 24 hours at $10^{\circ} \mathrm{C}$. All samples were washed three times by distilled water and were soaked in $30 \mathrm{ml}$ of distilled water for other 24 hours at $10^{\circ} \mathrm{C}$. Cell membrane stability (CMS) called injury was estimated from the following equation:

$$
\mathrm{I}=\left[1-\left(1-\mathrm{T}_{1} / \mathrm{T}_{2}\right) /\left(1-\mathrm{C}_{1} / \mathrm{C}_{2}\right)\right] \times 100,
$$

where:

$\mathrm{T}_{1}$ and $\mathrm{T}_{2}$ are the first and second (after autoclaving) measurement of the electro-conductivity of the solutions in which the treated samples were immersed, and

$\mathrm{C}_{1}$ and $\mathrm{C}_{2}$ are the related values for the controls. 
84

\section{Forage yield}

To measure forage yield, the aboveground weights of plants were oven-dried at $75^{\circ} \mathrm{C}$ for 48 hours.

\section{Statistical analysis}

Statistical analysis was performed using SAS software and mean comparisons were also performed using $\mathrm{LSD}_{5 \%}$. Regression analysis and set of equations were conducted using Minitab software.

\section{Results and Discussion}

\section{Photosynthetic indices}

It was found that water stress and seeds inoculation significantly influenced photosynthetic indices $(\mathrm{P}<0.05)$. The water restriction reduced photosynthetic indices while seeds inoculation played an important role in mitigating the impacts of stress. Severe stress (35\% FC) significantly decreased Chlorophyll $a$, Chlorophyll $b$, total Chlorophyll, carotenoid content and quantum yield by $23,24,24,35$ and $50 \%$, respectively compared to non-stressed. Seed inoculation improved photosynthetic indices and the application of $G$. mussea produced better results in terms of all these indices than S. meliloti. However, the double inoculation treatment resulted in the highest amount of Chlorophyll $a$, Chlorophyll $b$, total Chlorophyll and carotenoid content. In addition, it was revealed that combined inoculation had less effect on quantum yield, so unlike other traits, the highest quantum yield was obtained by inoculation with G. mussea (Table 1).

Leaf Chlorophyll content is a key parameter in determining photosynthesis and dry matter production. Chlorophylls destroy by reactive oxygen species and hydrogen peroxidase (Navari-Izzo et al., 1990; Ghosh et al., 2004).

The results of this study also confirmed the altering of photosynthetic indices under stress, The mycorrhizal symbiosis in rhizosphere helps the plants uptake water and nutrients including $\mathrm{P}, \mathrm{Fe}$, and $\mathrm{K}$ and reducing $\mathrm{Na}$ under stress conditions (Chen et al., 2003; Soliman et al., 2014). The increased absorption of micro and macro-elements under double inoculation with mycorrhizal and bacteria can supply the $\mathrm{N}$ and Fe deficiency caused by stress and could increase the photosynthesis and restore the production of photosynthetic pigments (Soliman et al., 2014). In addition, as root hydraulic conductivity and water uptake is increased by inoculation, the turgor of cells is re-established and subsequently, their growth increased and results in greater radial absorption and photosynthesis. The higher level of photosynthesis and the accumulation of carotenoids mitigates $\mathrm{NADPH} / \mathrm{NADP}^{+}$ ratio, prevents photo-inhibition and increase quantum yield (Conming and Zang, 2000).

There were a linear relationships between $\mathrm{Chl} a, \mathrm{Chl} b$ and total $\mathrm{Chl}$, a quadratic relationship between $\mathrm{Chl} a$, carotenoid and quantum yield, and total Chlorophyll had the greatest role $\left(\mathrm{R}^{2}=0.983\right)$ in predicting Chl $a$. Furthermore, Chl $b$ had $a$ linear relationship with total $\mathrm{Chl}$, carotenoid and quantum yield among which carotenoid had the greatest impact $\left(\mathrm{R}^{2}=0.949\right)$ in predicting it. The variations of Chlorophyll $b$ and total Chlorophyll were proportional to those of Chl $a$ so the increase in their quantities resulted in the increase in $\mathrm{Chl} a$, whereas the increase in carotenoid and quantum yield at lower levels depended to the increase in $\mathrm{Chl} a$ (Table 2).

Given the fact that $\mathrm{Chl} a$ plays the main role in the absorption and transfer of electrons from photosystem II to reaction centre of photosynthesis, it is the key in determining photosynthetic capacity. Carotenoids can protect light harvesting systems of photosynthesis against radical oxygen species (ROS). Also, they use oxygen in xanthophyll cycle and protect Chlorophyll against photo-oxidation (Koyro, 2006). The linear relationship between carotenoids and quantum yield, also, confirms this argument (Table 2).

\section{Compatiblesolutes}

Water-deficit increased proline and soluble sugars, while osmotic potential and membrane stability decreased $(\mathrm{P}<0.05)$. Severe stress (35\% FC) enhanced proline by 2.20 fold and soluble sugars $87 \%$, but osmotic potential and membrane stability decreased $85 \%$ and $40 \%$ respectively. In addition, it was observed that inoculation of seeds with stimulators affected osmotic adjustment $(\mathrm{P}<0.05)$. The inoculation of the seeds increased proline and membrane stability moreover, decreased soluble sugars and osmotic potential. The inoculation of seeds with G. mussea resulted in better performance of compatible solutes than $S$. meliloti, so that it caused the highest proline and soluble sugars content. However, double inoculation of seeds

Table 1. Effect of seed inoculation on Photosynthetic indices ( Chl $a, b$, total and carotenoid content, $\left.\mathrm{F}_{\mathrm{V}} / \mathrm{F}_{\mathrm{M}}\right)$ of alfalfa

\begin{tabular}{|c|c|c|c|c|c|c|}
\hline \multicolumn{2}{|c|}{ Treatment } & \multirow{2}{*}{$\begin{array}{c}\mathrm{Chl} a \\
\left(\mathrm{mgg}^{-1} \mathrm{FW}\right)\end{array}$} & \multirow{2}{*}{$\begin{array}{c}\mathrm{Chl} b \\
\left(\mathrm{mgg}^{-1} \mathrm{FW}\right)\end{array}$} & \multirow{2}{*}{$\begin{array}{c}\text { Total Chl } \\
\left(\mathrm{mgg}^{-1} \mathrm{FW}\right)\end{array}$} & \multirow[b]{2}{*}{$\begin{array}{l}\text { Carotenoid } \\
\left(\mathrm{mgg}^{-1} \mathrm{FW}\right)\end{array}$} & \multirow[b]{2}{*}{$\mathrm{F}_{\mathrm{V}} / \mathrm{F}_{\mathrm{M}}$} \\
\hline $\begin{array}{l}\text { Irrigation } \\
\text { schedules }\end{array}$ & Seed inoculation & & & & & \\
\hline \multirow{4}{*}{$75 \%$} & Control & $1.55 \pm 0.04$ & $1.61 \pm 0.01$ & $3.16 \pm 0.04$ & $16.09 \pm 0.2$ & $0.77 \pm 0.02$ \\
\hline & G. mussea & $2.03 \pm 0.03$ & $1.70 \pm 0.02$ & $3.73 \pm 0.01$ & $17.53 \pm 0.4$ & $0.80 \pm 0.00$ \\
\hline & S. meliloti & $1.91 \pm 0.06$ & $1.67 \pm 0.01$ & $3.58 \pm 0.05$ & $16.41 \pm 0.4$ & $0.79 \pm 0.02$ \\
\hline & $S+G$ & $2.32 \pm 0.02$ & $1.85 \pm 0.00$ & $4.16 \pm 0.03$ & $19.04 \pm 0.2$ & $0.77 \pm 0.00$ \\
\hline \multirow{5}{*}{$55 \%$} & Control & $1.22 \pm 0.01$ & $1.38 \pm 0.01$ & $2.60 \pm 0.02$ & $13.08 \pm 0.8$ & $0.70 \pm 0.10$ \\
\hline & G. mussea & $1.63 \pm 0.03$ & $1.54 \pm 0.01$ & $3.17 \pm 0.04$ & $15.23 \pm 0.5$ & $0.74 \pm 0.05$ \\
\hline & S. meliloti & $1.64 \pm 0.03$ & $1.47 \pm 0.01$ & $3.12 \pm 0.02$ & $14.80 \pm 0.4$ & $0.74 \pm 0.06$ \\
\hline & $S+G$ & $2.06 \pm 0.05$ & $1.65 \pm 0.00$ & $3.71 \pm 0.05$ & $16.24 \pm 0.9$ & $0.78 \pm 0.01$ \\
\hline & Control & $1.18 \pm 0.02$ & $1.22 \pm 0.01$ & $2.40 \pm 0.02$ & $10.37 \pm 0.5$ & $0.38 \pm 0.21$ \\
\hline \multirow{3}{*}{$35 \%$} & G. mussea & $1.40 \pm 0.02$ & $1.38 \pm 0.01$ & $2.78 \pm 0.03$ & $13.19 \pm 0.4$ & $0.78 \pm 0.00$ \\
\hline & S. meliloti & $1.37 \pm 0.03$ & $1.31 \pm 0.01$ & $2.68 \pm 0.04$ & $11.98 \pm 0.3$ & $0.61 \pm 0.24$ \\
\hline & $S+G$ & $1.72 \pm 0.04$ & $1.47 \pm 0.01$ & $3.19 \pm 0.04$ & $14.33 \pm 0.4$ & $0.75 \pm 0.00$ \\
\hline $\operatorname{LSD}_{0.05}$ & & 0.062 & 0.018 & 0.063 & 0.89 & 0.16 \\
\hline
\end{tabular}


Table 2. The regression equations between photosynthetic indices

\begin{tabular}{ccccc}
\hline Independent & Dependent & Regression equations & $\mathrm{R}^{2}$ & $\mathrm{n}$ \\
\hline \multirow{4}{*}{$\mathrm{Chl} a$} & $\mathrm{Chl} b$ & $\mathrm{y}=1.076+(1.084 \mathrm{x})$ & 0.856 & 36 \\
& Total Chl. & $\mathrm{y}=-0.458+(0.666 \mathrm{x})$ & 0.983 & 36 \\
& Carotenoid & $\mathrm{y}=1.321-(0.0912 \mathrm{x})+\left(0.00751 \mathrm{x}^{2}\right)$ & 0.831 & 36 \\
& $\mathrm{~F}_{\mathrm{V}} / \mathrm{F}_{\mathrm{M}}$ & $\mathrm{y}=2.068-(4.523 \mathrm{x})+\left(5.324 \mathrm{x}^{2}\right)$ & 0.338 & 36 \\
\hline \multirow{2}{*}{$\mathrm{Chl} b$} & Total Chl. & $\mathrm{y}=0.458+(0.333 \mathrm{x})$ & 0.935 & 36 \\
& Carotenoid & $\mathrm{y}=0.457+(0.071 \mathrm{x})$ & 0.949 & 36 \\
& $\mathrm{~F}_{\mathrm{V}} / \mathrm{F}_{\mathrm{M}}$ & $\mathrm{y}=1.008+(0.715 \mathrm{x})$ & 0.337 & 36 \\
\hline \multirow{2}{*}{ Total Chl. } & Carotenoid & $\mathrm{y}=-2.149-(0.0715 \mathrm{x})+\left(0.0092 \mathrm{x}^{2}\right)$ & 0.898 & 36 \\
Carotenoid & $\mathrm{F}_{\mathrm{V}} / \mathrm{F}_{\mathrm{M}}$ & $\mathrm{y}=1.809+(1.926 \mathrm{x})$ & 0.290 & 36 \\
\hline
\end{tabular}

Table 3. Effect of seed inoculation on compatible solutes, osmotic Potential and cell membrane stability of alfalfa

\begin{tabular}{|c|c|c|c|c|c|}
\hline \multicolumn{2}{|c|}{ Treatment } & \multirow{2}{*}{$\begin{array}{c}\text { Proline } \\
(\mu \mathrm{gg}-1 \mathrm{FW})\end{array}$} & \multirow{2}{*}{$\begin{array}{c}\text { Soluble Sugar (mg g -1 } \\
\text { FW) }\end{array}$} & \multirow{2}{*}{$\begin{array}{l}\text { Osmotic Potential } \\
\text { (bar) }\end{array}$} & \multirow{2}{*}{$\begin{array}{c}\text { Membrane stability } \\
(\%)\end{array}$} \\
\hline $\begin{array}{l}\text { Irrigation } \\
\text { schedules }\end{array}$ & Seed inoculation & & & & \\
\hline \multirow{4}{*}{$75 \%$} & Control & $1.50 \pm 0.045$ & $3.24 \pm 0.036$ & $-10.24 \pm 0.65$ & $53.00 \pm 2.00$ \\
\hline & G. mussea & $3.23 \pm 0.030$ & $3.04 \pm 0.038$ & $-9.51 \pm 0.61$ & $63.33 \pm 1.53$ \\
\hline & S. meliloti & $2.71 \pm 0.031$ & $3.03 \pm 0.052$ & $-9.50 \pm 0.25$ & $69.00 \pm 2.00$ \\
\hline & $S+G$ & $4.65 \pm 0.035$ & $2.95 \pm 0.045$ & $-10.22 \pm 0.07$ & $71.00 \pm 1.00$ \\
\hline \multirow{4}{*}{$55 \%$} & Control & $2.24 \pm 0.032$ & $4.55 \pm 0.045$ & $-13.35 \pm 0.56$ & $46.33 \pm 1.53$ \\
\hline & G. mussea & $4.33 \pm 0.026$ & $3.41 \pm 0.061$ & $-9.59 \pm 0.16$ & $58.67 \pm 1.15$ \\
\hline & S. meliloti & $3.80 \pm 0.035$ & $3.27 \pm 0.021$ & $-12.59 \pm 0.21$ & $63.00 \pm 2.00$ \\
\hline & $S+G$ & $5.62 \pm 0.021$ & $2.98 \pm 0.035$ & $-12.44 \pm 0.13$ & $67.00 \pm 2.00$ \\
\hline \multirow{4}{*}{$35 \%$} & Control & $4.77 \pm 0.021$ & $6.06 \pm 0.051$ & $-18.91 \pm 0.35$ & $32.33 \pm 2.52$ \\
\hline & G. mussea & $5.63 \pm 0.023$ & $5.27 \pm 0.021$ & $-12.92 \pm 0.06$ & $39.33 \pm 1.15$ \\
\hline & S. meliloti & $5.16 \pm 0.050$ & $5.03 \pm 0.031$ & $-15.48 \pm 0.66$ & $42.00 \pm 1.73$ \\
\hline & $S+G$ & $7.14 \pm 0.040$ & $4.74 \pm 0.032$ & $-16.29 \pm 0.28$ & $46.33 \pm 1.53$ \\
\hline $\operatorname{LSD}_{0.05}$ & & 0.056 & 0.068 & 0.676 & 2.918 \\
\hline
\end{tabular}

Values represent the average of three replicates per treatment \pm SE $\left(\mathrm{LSD}_{5 \%}\right)$.

Table 4. The relationship between compatible solutes and cell membrane stability

\begin{tabular}{ccccc}
\hline Independent & Dependent & Regression equations & $\mathrm{R}^{2}$ & $\mathrm{n}$ \\
\hline \multirow{3}{*}{ Proline } & Soluble Sugar & $\mathrm{y}=84.83-(58.18 \mathrm{x})+\left(13.36 \mathrm{x}^{2}\right)-\left(0.979 \mathrm{x}^{3}\right)$ & 0.163 & 36 \\
& osmotic potential & $\mathrm{y}=0.749-(0.276 \mathrm{x})$ & 0.275 & 36 \\
& membrane stability & $\mathrm{y}=5.940+(0.0314 \mathrm{x})$ & 0.064 & 36 \\
Soluble Sugar & osmotic potential & $\mathrm{y}=0.098-(0.307 \mathrm{x})$ & 0.736 & 36 \\
Osmotic Potential & membrane stability & $\mathrm{y}=3.75+(0.301 \mathrm{x})-\left(0.0095 \mathrm{x}^{2}\right)+\left(0.000072 \mathrm{x}^{3}\right)$ & 0.947 & 36 \\
\hline
\end{tabular}

with G. mussea and S. meliloti resulted in the highest proline amount and membrane stability under both stress and optimum conditions (Table 3).

Also, regression equations revealed that the variations of soluble sugar significantly related to the proline amount under stress conditions. In addition, the correlation of proline with osmotic potential was higher than that with membrane leakage rate. Nonetheless, osmotic potential had the highest effect $\left(R^{2}=0.736\right)$ in predicting the soluble sugars (Table 4$)$.

The results of the present study are in agreement with those reported by Dehqanzadeh et al. (2008). It seems that during stress, cell water potential goes down the threshold and the synthesis of proline is enhances with increasing in proteolysis enzymes activity to increase water uptake. It is shown that the increase in proline biosynthesis with the supply of $\alpha$-glutarate metabolite by sugars is possible (Ghorbanli and Niakan, 2005). Proline accumulation in stress condition is a defensive mechanism (Koocheki et al., 2004). So, proline accumulation protects the plant by osmotic adjustment as well as by stabilizing many functional units like complex II of the electron transport system and removal of hydroxyl radicals (Mattioli $e t$ al., 2009). Proline reduces cytoplasmic $\mathrm{pH}$ and maintains the proper ratio of NADP + / NADPH in metabolism and increase different enzymes activities (Szabados and Savoure, 2009).

A solution stabilizes the water potential of vacuoles and reduces cell osmotic potential (Masour et al., 2005). Moreover, results showed the decrease in osmotic potential during stress. The decrease in osmotic potential via accumulation of minerals and other solutes in cells for maintenance of turgor potential to help the cell growth and development under stress condition. Stress causes the oxidation of cell membrane fatty acids and the destruction of membrane stability through producing toxic radicals and free oxygen, as well (Wang \& Huang, 2004). Sugars can cause the osmotic adjustment, membrane stability and drying proteins besides it can prevent the condensation of phospholipids by replacing the water of lipid membrane (Irigoyen et al., 1992). The results of regression also confirm the close relationship between membrane stability and soluble sugars, the application of growth stimulators improved the osmotic adjustment indices resulting in greater stress tolerance. Such results have been reported in other studies, as well (Kaschuk et al., 2010). 
86

\section{Forage yield}

Forage yield was influenced by water-deficit stress and the inoculation of seeds with growth stimulators $(P<0.05)$. Water-deficit stress reduced forage yield so that the severe stress ( $35 \%$ FC) resulted in $27 \%$ forage loss. The application of growth stimulators increased the yield. Double inoculation gave rise to the highest forage yield and there was no significant difference between the inoculation treatments with G. mussea or S. meliloti (Fig. 1).

Regression equations showed that among photosynthetic indices, the $\mathrm{Chl} b$ and carotenoid had the highest effect in predicting forage yield. The relationship of yield with carotenoid and $\mathrm{Chl} b$ was quadratic. Therefore, lower levels of $\mathrm{Chl} b$ and carotenoid had more effect than their higher levels. The relationship of $\mathrm{Chl}$ a and total $\mathrm{Chl}$ and quantum yield with forage yield were linear. Among osmotic adjustment indices, soluble sugar and membrane stability had the highest impact in predicting the yield. The variation of soluble sugar and yield was of cubic kind and the variation of yield and membrane stability was as quadratic. Therefore, the increase in soluble sugar resulted in the loss of forage yield, but the higher membrane stability increased alfalfa forage yield.

Results revealed that stress decreased osmotic and turgor potential besides, since the growth and development of cell relies upon turgor, the development and the size of the cells are reduced and result in the loss of leaf area, intercepted light and photosynthesis and also result in the loss of leaf and shoot dry matter (Nilsen \& Orcutt, 1996; Desuloux et al., 2000). The production of compatible solutes increases the plants expense on the consumption of $\mathrm{N}$ and $\mathrm{C}$ and on the other hand, the loss of photosynthesis during stress results in yield loss. Regression results confirmed the high impact of osmotic potential, $\mathrm{Chl} b$ and carotenoid in predicting forage yield. Additionally, it was observed that greater production of proline and soluble sugar resulted in forage yield loss (Fig. 2). The application of growth stimulators mitigated the adverse effects of the stress and increased the yield by improving photosynthetic indices as well as increasing osmotic

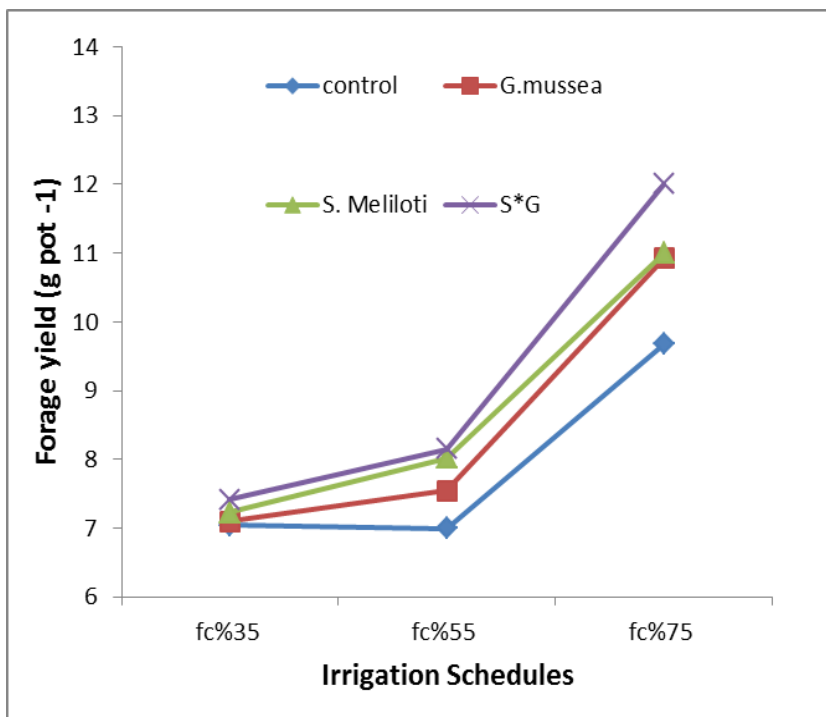

Fig. 1. Effect of seed inoculation on forage yield of alfalfa under water limitation
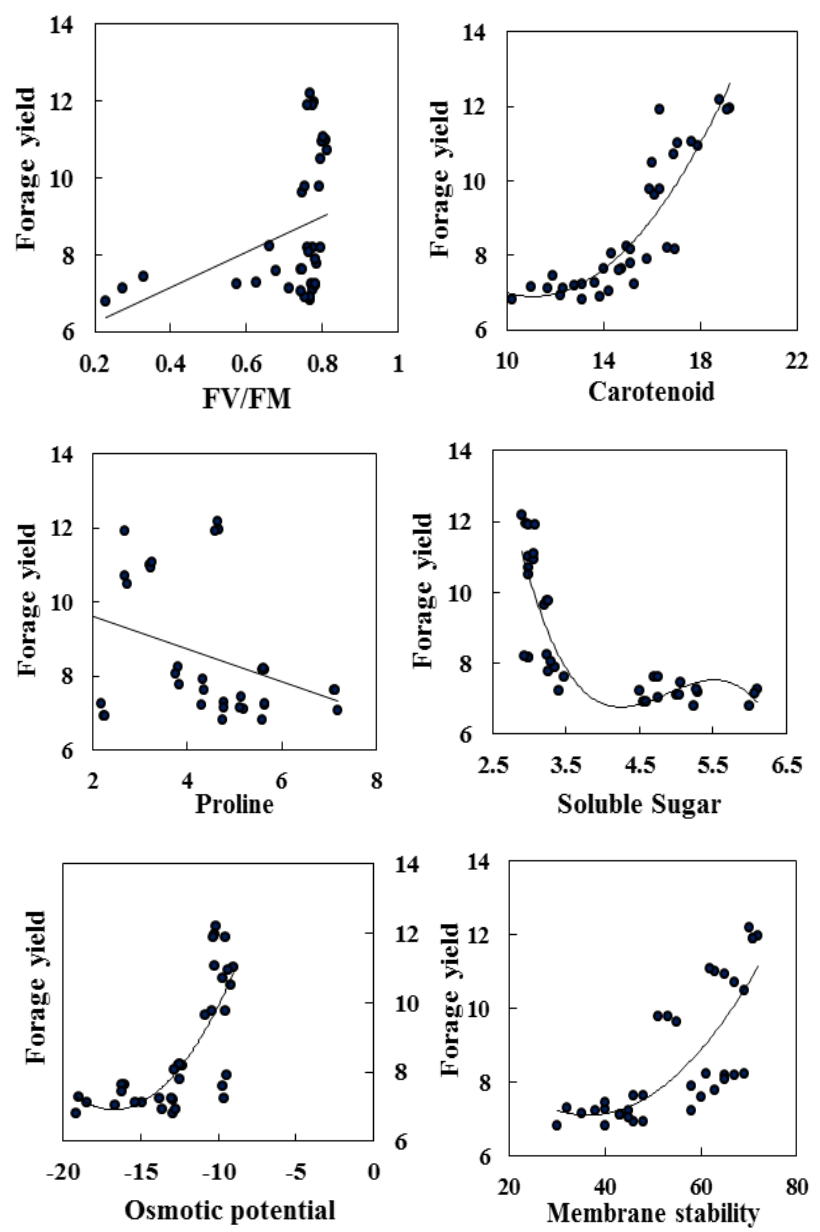

Fig. 2. Regression models forage yield changes by of alfalfa

adjustment. In addition, it has been shown that as a result of inoculation, the presence of fungal hyphae resulted in the uptake of water and nutrients by plant leads to higher yield of the plant (Baon et al., 1994; Soliman et al., 2014).

\section{Conclusions}

It was found that water-deficit stress reduced osmotic potential, membrane stability and photosynthetic indices. The loss of osmotic potential and membrane stability as well as photosynthetic indices resulted in the loss of turgor potential and the required energy for the division and cell elongation and finally losses the forage yield. Under stress condition, plants increased their tolerance by producing adaptive metabolites (proline and soluble sugars). Also, it was observed that among the measured indices $\mathrm{Chl} b$, carotenoid and soluble sugar had the highest effect in predicting forage yield. The inoculation of the seeds with growth stimulators improved the uptake of water by plant through forming hyphae in rhizosphere which decreased the effects of stress, improved photosynthetic indices, increased $\mathrm{N}$ and $\mathrm{C}$ sources of the plant for the production of compatible solutes and, improved the stress tolerance of the plant. The application of mycorrhiza plus rhizobia had the highest effect on measured traits owing to their synergistic relationship. 


\section{References}

Allison MF, Armstrong MJ, Jaggard KW, Todd AD, Milford GJ (2002). An analysis of the agronomic, economic and environmental effect of applying $\mathrm{N}$ fertilizer to sugar beet (Beta vulgaris L.). Journal of Agricultural Science 127:475- 486.

Arnon AN (1967). Method of extraction of chlorophyll in the plants. Agronomy Journal 23:112-121.

Arnon DI (1949). Copper enzymes in isolated chloroplast polyphenol oxidase in Beta vulgaris. Plant Physiology 24:1-15.

Bajji M, Lutts S, Kinet JM (2001). Water deficit effects on solute contribution to osmotic adjustment as a function of leaf aging in three durum wheat (Triticum durum Desf.) cultivars performing differently in arid conditions. Plant Science 160:669-681.

Baon JB, Smith SE, Alston AM (1994). Growth and phosphorus uptake of rye with long and short root hairs: interaction with mycorrhizal infection. Plant and Soil 197:247-254.

Barea JM, Pozo MJ, Azcon R, Azcon-Aguilar C (2005). Microbial cooperation in the rhizosphere. Journal of Experimental Botany 56:1761-1778.

Bates LS, Waldren RP, Teare ID (1973). Rapid determination of free proline for water stress studies. Plant and Soil 39:205-207.

Biro B, Voros I, Koves-Pechy K, Takacs T, Eggenberger P, Strasser R J ( 2000). Interrelation between Azospirillum and Rhizobium nitrogen-fixers and arbuscular mycorrhizal fungi in the rhizosphere of alfalfa in sterile, AMF-free or normal soil conditions. Applied Soil Ecology 15:159-168.

Blum B, Ebercon A (1981). Cell membrane stability as a measure of drought and heat tolerance in wheat. Journal of Crop Science 21:43-47.

Chen BD, Li XL, Tao HQ, Christie P, Wong MH (2003). The roll of Mycorrhiza in zinc uptake by red clover growing calcareous soil spiked with various quantities of zinc. Chemosphere 60 (6):939-846.

Chogan R (2003). Maize breeding for drought tolerance and nitrogen. Tehran, Iran: Ministry of Agriculture.

Conming L, Zang J (2000). Photosynthetic $\mathrm{CO}_{2}$ assimilation chlorophyll fluorescence and photoinhibition as affected by nitrogen deficiency in maize plants. Journal of Plant Science 151:135-143.

Cui YY, Pandey D M, Hahn EJ, Paek KY (2004). Effect of drought on physiological aspects of Crassulacean acid metabolism in Doritaenopsis. Journal of Plant Science 167:1219-1226.

Dehqanzadeh H, Khajehpour MR, Heidari Sharif Abad H, Soleimani AS (2008). Effect of limited irrigation on the accumulation of proline, free soluble sugars and potassium in bread wheat cultivars. 10th Iranian Congress of Agronomy and Plant Breeding Sciences.

Desuloux D, Huynh TT, Roumet P (2000). Identification of soybean plant characteristics that indicate the timing of drought stress. Journal of Crop Science 40:716-722.

Follows RJ, Boyer JS (1996). Structure and activity of Chloroplasts of sunflower leaves having various water potentials. Planta 132:229-239.

Ghosh PK, Ajay KK, Bandyopadhyay MC, Manna KG, Mandal AK, Hati KM (2004). Comparative effectiveness of cattle manure, poultry manure, phosphocompost and fertilizer-NPK on three cropping systems in vertisols of semi-arid tropics. I. Crop yields and system performance. Bioresource Technology 95: 85-93.

Hirt H, Shinozaki K (2004). Plant responses to abiotic stress. Berlin, Germany: Springer-Verlag Berlin Heidelberg.

Janardhan KV, Krishnamoorthy V (1975). A rapid method for determination of osmotic potential of plant cell. Current Science 44 (1):390-391.

Javaid A (2010). Role of arbuscular mycorrhizal fungi in nitrogen fixation in legumes. In: Khan MS, Musarrat J, Zaidi A (Eds). Microbes for Legume Improvement. Springer-Verlag, Berlin pp 409-426.

Karo M, Mishra D (1976). Catalase, peroxidase and polyphenol oxidase activity during rice leaf senescence. Plant Physiology 57:315-319.

Kaschuk G, Leffelaar PA, Giller KE, Alberton O, Hungria M, Kuyper TW (2010). Responses of legumes to rhizobia and arbuscular mycorrhizal fungi: a metaanalysis of potential photosynthate limitation of symbioses. Soil Biology and Biochemistry 42(1):125127.

Koocheki E, Zand E, Bannayan M, Rezvani Moghaddam P, Mahdavi Damghani A, Jami Al Ahmadi M, Vesal SR (2004). Plant physiological ecology. Ferdowsi University of Mashhad Press.

Koyro HW (2006). Effect of salinity on growth, photosynthesis, water relations and solute composition of potential cash crop halophyte Plantago coronopus (L.). Environmental and Experimental Botany 56:136149.

Lacefield GD, Ball DM, Hancock D, Andrae J, Smith R (2009). Growing alfalfa in the south. National Alfalfa and Forage Alliance. https://www.alfalfa.org/pdf/alfalfainthesouth.pdf.

Masour MM, Salama KH, Ali FM, Abou Hadid AF (2005). Cell and plant responses to $\mathrm{NaCl}$ in Zea mays $\mathrm{L}$. cultivars differing in salt tolerance. General and Applied Plant Physiology 31(1-2):29-41.

Mattioli R, Costantino P, Trovato M (2009). Proline accumulation in plants: not only stress. Plant Signaling \& Behavior 4(11):1016-1018. 
Navari-Izzo F, Quartacci MF, Izzo R (1990). Water-stress induced changes in protein and free amino acids in field grown maize and sunflower. Plant Physiology Biochemistry 28:531-537.

Ndoumou OD, Ndzomo TG, Djocgoue PF (1996). Changes in carbohydrate, amino acid and phenol contents in cocoa pods from three clones after infection with Phytophthora megakarya Bra. and Grif. Annals of Botany 77(2):153-158.

Nilsen ET, Orcutt DM (1996). Physiology of plant under stress (abiotic factors). New York, US: John-Wiley and Sons.

Puppi G, Azcon R, Hoflich G (1994). Management of positive interactions of arbuscular mycorrhizal fungi with essential groups of soil microorganisms. In: Gianinazzi S, Schüepp H (Eds). Impact of Arbuscular Mycorrhizas on Sustainable Agriculture and Natural Ecosystems. Bikhauser, Berlin pp 201-215.

Rahnama H, Ebrahimzadeh $\mathrm{H}$ (2004). The effect of $\mathrm{NaCl}$ on proline accumulation in potato seedlings and calli. Physiologia Plantarum 26(3):263-270.

Shimshi D, Mayoral ML, Atsmond D (1992). Response to water stress in wheat and related wild species. Crop Science 22:123-128.

Singh S, Kapoor KK. 1999. Inoculation with phosphate solubilizing microorganisms and a vesicular arbuscular mycorrhizal fungus improves dry matter yield and nutrient uptake by wheat grown in sandy soil. Biology and Fertility of Soils 28:139-144.
Soliman AS, Shanan NT, Massoud ON, Swelim DM (2014). Improving salinity tolerance of Acacia saligna (Labill.) plant by arbuscular mycorrhizal fungi and Rhizobium inoculation. African Journal of Biotechnology 11(5):1259-1266.

Stewart RC, Bewley JD (1980). Lipid peroxidation associated aging of soybean axes. Plant Physiology 65:245-248.

Sunka R, Bartel D, Kirch HH (2003). Over expression of a stress inducible dehydrogenas gene from Arabidopsis thaliana in transgenic plants improves stress tolerance. The Plant Journal of Agricultural Science 32(1):73-86.

Szabados L, Savoure A (2009). Proline: a multifunctional amino acid. Trends in Plant Science 15(2):89-97.

Wang Z, Huang B (2004). Physiological recovery of Kentucky bluegrass from simultaneous drought and heat stress. Journal of Crop Science 44:1729-1736.

Yordanov I, Tsonev T (2003). Plant responses to drought and stress tolerance. Bulgarian Journal of Plant Physiology (Sp Issue):189-206.

Zahir AZ, Abbas SA, Khalid A, Arsaad M (2000). Substrate depended microbially plant hormones for improving growth of maize seedling. Pakistan Journal of Biological Science 3:289-291. 